Reading Heresy 



\section{Reading Heresy}

Religion and Dissent in Literature and Art

Edited by

Gregory Erickson and Bernard Schweizer

\section{DE GRUYTER}


ISBN 978-3-11-055594-3

e-ISBN (PDF) 978-3-11-055682-7

e-ISBN (EPUB) 978-3-11-055603-2

\section{Library of Congress Cataloging-in-Publication Data}

A CIP catalog record for this book has been applied for at the Library of Congress.

Bibliografic information published by the Deutsche Nationalbibliothek

The Deutsche Nationalbibliothek lists this publication in the Deutsche Nationalbibliografie; detailed bibliografic data are available on the Internet at http://dnb.dnb.de.

(C) 2017 Walter de Gruyter GmbH, Berlin/Boston

Cover image: manjik/Stock/Getty Images Plus

Printing and binding: CPI books $\mathrm{GmbH}$, Leck

(2) Printed on acid-free paper

Printed in Germany

www.degruyter.com 